\title{
Some Thoughts on Ecological Marxism
}

\author{
Zhiyan Li \\ Yunnan Normal University, Kunming, China \\ Email: 1345310779@qq.com
}

How to cite this paper: Li, Z. Y. (2021). Some Thoughts on Ecological Marxism. Open Journal of Social Sciences, 9, 212-219. https://doi.org/10.4236/jss.2021.912014

Received: November 8, 2021

Accepted: December 10, 2021

Published: December 13, 2021

Copyright $\odot 2021$ by author(s) and Scientific Research Publishing Inc. This work is licensed under the Creative Commons Attribution International License (CC BY 4.0).

http://creativecommons.org/licenses/by/4.0/

\begin{abstract}
By means of literature research, this paper will attempt to conclude the background and nature of ecological Marxism, will illustrate and analyze its four theories: ecological crisis, alienation consumption, steady-state economic model and ecological socialism. These theories strengthened socialist ideal and belief, however, they have obvious deficiencies in such aspects as replacing the basic conflict of capitalist society by the conflict between human and ecology, restraining the increasingly growing material and cultural needs of people with "zero economic growth", and opposing "violent revolution".
\end{abstract}

\section{Keywords}

Ecological Socialism, Western Marxism, Ecological Marxism, Socialism

Ecological Marxism is one of the latest and the most influential thoughts of contemporary western Marxism (Chen \& Tang, 2014). In 1979, Ben. Agger first applied the concept of ecological Marxism in his An Introduction to Western Marxism. Domestic study of Ecological Marxism started in the 1980s. It aims to analyze the root causes of ecological crisis in capitalism and seek ways to solve it. It can not only provide a new perspective for us on scientifically understanding contemporary capitalism, but also strengthen the ideal and belief of socialism. This paper will attempt to investigate and analyze ecological Marxism.

\section{Introduction}

In 1986, Professor Wang Jin was the first to introduce ecological Marxism into China, and its systematic research on ecological Marxism began in the 1990s. All western Marxist textbooks published in the 1990s, such as Foreign Marxist Philosophy Schools by Yu Wujin and Chen Xueming, have discussions on Ecological Marxism. In 2007, Liu Rensheng published an Introduction to Ecological Marxism in Central Compilation \& Translation Press, which is China's first 
book to study systematically of ecological Marxism. After him, a number of doctoral theses on ecological Marxist research published. The representatives' works of ecological Marxism have been translated into Chinese successively, gradually forming a climax of domestic research on ecological Marxism.

They all had a fierce debate on the definition domain of ecological Marxism. The domestic scholars think that ecological Marxism is the result of Western Marxism paying attention to ecology (Liu, 2007); or that ecological Marxism is a kind of postmodern Marxism that fundamentally rejects the mode of productivity growth of historical materialism; Or think that ecological Marxism is a representative that has strong Marxist tendency in the ecological socialism camp. It consciously uses Marxist viewpoints and methods to analyze the environmental degradation and ecological crisis of contemporary capitalism, to explore the solutions for environmental problems (Yu \& Chen, 2002). Wang Yuchen believes "Ecological Marxism is a new school of Marxism, which applies Marxist historical analysis method and class analysis method to criticize contemporary western capitalist system and mode of production from the perspective of ecology, based on Marxist theory of the relationship between man and nature." (Wang, 2019) This is adopted in the definition of ecological Marxism in this paper.

\section{The Background and Nature of Ecological Marxism}

They all also had a fierce debate on its background and nature. In this section, the author will summarize their achievements on the background and the nature of ecological Marxism.

\subsection{The Background of Ecological Marxism}

The background of Ecological Marxism can be summarized as follows: 1) At the age of machines, social productive forces improved at a high speed, at the same time, capitalism use science and technology to accelerate the developing of natural resources, as a result, excessive discharge of waste caused serious pollution and damage to the ecological environment (Zhang \& Jiang, 2020); 2) Global capitalism spread, humans have been facing serious survival challenges, successive ecological movement and the emergence of the Green Party have provided an organizational foundation for ecological Marxism; 3) In capitalist society, the alienation of production and consumption has magnified the ecological crisis (Bao, 2012); 4) New Ecological and environmental issues keep intruding, which needs people's reply (Ji \& Li, 2021).

\subsection{The Nature of Ecological Marxism}

On the nature of ecological Marxism, the main views are as follows: 1) Ecological Marxism is a supplement to Marxism, trying to help developed capitalist countries eliminate the ecological crisis and move towards ecological socialism (Zhu \& Wu, 2021); 2) Ecological Marxism is one of the trends of western Marxism, and the modernization results of western Marxism solving new social prob- 
lems; 3) Ecological Marxism is the premise of realizing ecological socialism, without ecological Marxism, ecological socialism is fully theoretic; 4) Ecological Marxism advocates eliminating alienation labor and establishing steady-state economic model, and insists on human-centered values (Bao, 2020); 5) Ecological Marxism advocates replacing mass production by small one, and hopes to eliminate social problems through social ideological revolution, so Ecological Marxism is also partly considered as combination of Utopian socialist and revivalism (Cui, 2021).

\section{Four Ecological Marxist Theories}

Ecological crisis, alienation consumption, steady-state economic model, and ecological socialism will be illustrated and analyzed in this section.

\subsection{Ecological Crisis}

Starting from the capitalism society at the time, surveying various phenomena and problems carefully, ecological Marxists summed up the two major characteristics of capitalist development as "overproduction" and "over-consumption" (Han, 2012). "Overproduction" refers to capitalists constantly expand the scale of production and reproduction, because of their greed in nature and their goal to maximize profits (Meng, 2021). It makes the development and waste of natural resources in capitalist society inevitable. Although capitalists are under pressure and have to deal with the ecological crisis, their greed in nature and their goal to maximize profit make environmental governance secondary to the pursuit of interests. Ecological crisis cannot be solved. "Over-consumption" is a phenomenon that people's happiness standard lies in amount of consumption and the number of consumption varieties. In this case, natural resources are also continuously over-developed to a greater extent to organize larger-scale "overproduction" to meet the needs of "over-consumption". At this time, the ecological crisis is intensifying. The vicious influence of "overproduction" and "over-consumption" on nature goes back and forth. Ecological Marxists further pointed out that the goal of capitalism has enabled capitalism countries to continue to explore markets. Relying on their advantages in capital and technology, they continuously occupy global resources to the maximum extent, and practice "ecological colonialism" against developing countries and plunder their limited resources, causing local environmental pollution, resource depletion and ecological environment problems. The globalization of capitalism eventually led to a global ecological crisis. In summary, ecological Marxists attribute the ecological crisis to the capitalism's mode of production, that is, the pursuit of profit maximization. It has made the relationship not only between bourgeoisie and proletariat but also between man and ecology worse (Wang, 2008). They believe that the ecological crisis has replaced the economic crisis and is more likely to become the cause of capitalist disasters, even global disasters, because the ecological crisis has threatened the survival of human beings. Capitalism cannot find a way out 
for ecological crisis.

\subsection{Alienation Consumption}

In the eyes of western Marxists, contemporary capitalist society is not a real consumption-oriented society, but a society with alienation consumption. The so-called alienation consumption refers to a phenomenon that people are committed to obtaining commodities in order to offset their tedious, non-creative, and under-compensated labor. It attempts to meet the needs of people's rich spirit through material consumption, so as to eliminate dissatisfaction with capitalism and people's ability to criticize the real society. In this way, people become a tool to maintain the rationality of capitalism. Alienation consumption leads to continuous capital accumulation, scale expansion of production and reproduction, destruction of ecological environment and intensive ecological crisis. Ecological Marxists believe that alienation consumption is the root cause of ecological crisis, so the way to solve the ecological crisis is to eliminate alienation consumption (Dong, 2020). Ecological Marxists also believe that the fundamental way to eliminate alienation consumption is to transform alienation production and create the "zero economic growth" model. In this model, ecology is placed in an important position, human needs are defined by ecological sustainability, social needs and rewarding consumption are taken as the starting point of production activities. For them, one's happiness lies in effective combination of self-realization at work and consumption (Wang, 2021). That is, production activities should be useful to society, and people's aspirations and values can be actualized in the process. Ecological Marxists stress the harmony between man and nature, and the consistency of the way of production and life, and principle of ecology.

\subsection{Steady-State Economic Model}

In this model, the mass production techniques are replaced by the small, production concentration and bureaucracy are replaced by production decentralization and democratization (Zhong, 2016). Western developed countries exploiting natural resources blindly and ignore ecological problems completely caused overproduction and over-consumption. Steady-state economic model considers this radical and emphasizes the importance of ecological environment and its protection, moderate development and rational use of natural resources. It is an economic model that not only maintains the ecological balance, but also maintains the long-term survival and development of mankind, and maintains sustained economic growth. In the view of ecological Marxists, based on technology, highly concentrated capital, highly intensive resources and delicacy division of labor, capitalist large-scale mechanized industry is violent and destructive in nature. While with less energy consumption, less damage to the environment, small production techniques are conducive to protecting and cultivating people's innovation consciousness and ability, showing people's intelligence and wisdom. 
Decentralized and democratic production can gradually overcome alienation production and alienation consumption. Ecological Marxists also pointed out, to create steady-state economic model is to decrease the production capacity of capitalism and emphasize the role of nation. In democratic and decentralized production, workmen have opportunities to directly participate in management, to show their intelligence and wisdom, in this way, the realization of self-value, and the growth of sustainable and stable economic are unified (Lin, 2018).

\subsection{Ecological Socialism}

With increasingly accelerating process of economic globalization, the scale of capitalist production and reproduction continuously expands (Yu, 2021). But natural resources are limited and non-renewable, such conflict is becoming increasingly prominent. Ecological Marxists think that capitalist production mode is the root of social injustice and ecological crisis, and the only way to solve the ecological crisis is to change capitalist production mode. Furthermore, to change the mode of production of capitalism is to transform capitalism into ecological socialism, by combing ecological movement with Marxism to guide the labor movement organically, by ripening the ecological movement into the political movement. Through the dual transformations of system and value, ecological crisis will be solved, and the beautiful situation of harmonious coexistence between man and nature will be achieved (Liu, 2006). Ecological Marxists described that production mode in ecological socialism is based on voluntary labor, and the development and the allocation of resources is based on the real needs of the people and plan. It is conducive to ecology. The purpose to establish ecological socialism is to use resources in reason, avoid resource depletion, and realize the common development of man and nature. This production mode can overcome capitalist alienation, overproduction and over-consumption (Li, 2021). Western ecological Marxists believe that the realization of ecological socialism is the necessary condition for the liberation of human and nature.

The study on four theories of ecological Marxism-Ecological crisis, alienation consumption, steady-state economic model, and ecological socialism will bring the author some thoughts on ecological Marxism.

\section{Some Thoughts on Ecological Marxism}

Based on the illustration and analysis before, the author thinks that ecological Marxism has its positive sides and negative sides.

\subsection{Positive Side}

Firstly, taking the increasingly prominent ecological crisis as its starting point and research content, ecological Marxism reflects the current situation of human beings destroying the ecology for economic growth, and strongly expresses its opposition, emphasizing the importance of uniformity between economic growth and ecological balance. This is not harmful but conducive to sustainable eco- 
nomic development, to the perpetuation of human society, and to the long-term peace of the world.

Secondly, capitalist system and mode of production are regarded as the root of ecological crisis by ecological Marxists. Ecological Marxism profoundly reveals the essence of ecological crisis and provides a new perspective for us to scientifically understand capitalism. Ecological Marxists also pointed out that the ecological crisis cannot be solved in capitalism, and the only way to solve the ecological crisis is to overthrow the capitalist system and its mode of production, then to carry out socialist revolution in order to establish ecological socialism. This provides us a powerful theoretical support for firming socialist ideal and belief.

Thirdly, the concept of consumption alienation in ecological Marxism is an extension of Marx's concept of labor alienation and production alienation. It points out that capitalist society is a morbid society in which the bourgeoisie exploits the proletariat, man exploits nature. The production mode in ecological socialism will overcome capitalism alienation, overproduction and over-consumption. People working in this mode will gain the essence of a community, which is a community of cognition rather than a community of interests. Such a society full of love for the ecology, and its system reflects social justice and fairness while avoiding ecological crisis. Ecological Marxists also point out that in ecological socialism, technology will be rationally utilized to protect nature instead of destroying it, and to make people at work will feel the happiness and satisfaction of production. Ecological socialism will not cause ecological crisis, will eliminate labor and production alienation in capitalism, and realize the liberation of man and nature.

\subsection{Negative Side}

Although ecological Marxism attaches importance to the issue of ecological crisis and provides us with a new theoretical perspective, it also has its obvious limitations, which are mainly manifested in three aspects.

Firstly, ecological Marxists replaces the economic crisis theory by ecological crisis, which means the conflict between man and nature replaces the basic conflict of capitalist society, and ecological Marxists denied the practical significance of Marx's economic crisis theory.

Secondly, in order to maintain ecological balance, ecological Marxism advocates the creation of a steady-state economic model. This kind of "zero growth" economic model is unrealistic and cannot meet the growing material and cultural needs of the people. It is unfair to developing countries. In this mode, replacing large-scale and concentrated production with small-scale and decentralized production is a historical retrogression at a time when productivity is highly developed.

Thirdly, ecological Marxists advocate the establishment of ecological socialism by the establishment of a "cognitive community" rather than "violent revolu- 
tion". In fact, it is impossible to fundamentally reform the bourgeoisie. It's just the vain "reformed capitalism", which is still capitalism in essence.

In this paper, by means of literature research, the author attempts to conclude the background and nature of ecological Marxism, illustrates and analyses ecological crisis, alienation consumption, steady-state economic model and ecological socialism, which are included in ecological Marxism. By illustrating and analyzing these theories, the author finds that ecological Marxism has its positive and negative sides, and its study has great significance.

\section{Conclusion}

The theoretical analysis of ecological Marxism not only provides an important way to understand the theory purport and paradigm shift of foreign Marxist, but also has an important referenced significance to the reflection on current ecological problems and theory construction of the ecological civilization with Chinese characteristics. Ecological Marxism, as one of the classic and influential schools in foreign Marxist theories, has grasped the current ecological lifeline of economic and social development with a high degree of acumen. While focusing on global ecological issues, it deeply criticized the anti-ecological nature of capitalism by the clue of the reason for the ecological destruction, and thus formed unique theories and insights revolving around the model of human social and economic development, the ecological problems of current and future capitalist society, and the development path of socialism.

Inevitably, with its some limitations, such as trying to replace economic crisis with the ecological crisis, pursuing unrealistic "steady-economic model" (the so-called "zero growth" economic model) while highlighting the importance of the ecological environment, and establishing ecological socialism through the establishment of a "cognitive community" etc., it has certain utopia color, and cannot effectively solve the global ecological problems, but to a certain extent, it provides a new perspective to re-examine and criticize the capitalist system. It is believed that, with the development of the times and the continuous improvement of theories, ecological Marxism can burst out more scientific views and achievements, continue to advance in theory and practice, and bring "ecological light" for the development of human beings.

\section{Conflicts of Interest}

The author declares no conflicts of interest regarding the publication of this paper.

\section{References}

Bao, A. R. G. L. (2020). A Review of Ben Agger's Ecological Crisis Theory. Tribune of Social Sciences, No. 4, 63.

Bao, D. Q. (2012). Comment on Agger's Alienated Consumption Theory of Ecological Marxism. Studies on Marxism, No. 4, 114.

Chen, J. M., \& Tang, Z. Q. (2014). Research on Ecological Marxism in Nearly Ten Years. 
Teaching and Research, No. 4, 105.

Cui, Y. J. (2021). Foster's Critique on the Ecological Morality of Capitalism and Enlightenment. Journal of Shandong Normal University (Social Sciences), No. 5, 110.

Dong, Q. Q. (2020). Alienation Change: From Alienated Labor to Alienated Nature, and Then to Alienated Consumption. Study \& Exploration, No. 3, 141.

Han, X. Sh. (2012). Review on Ecological Marxism at Home. Yangtze Tribune, No. 4, 15.

Ji, T., \& Li, A. T. (2021). Innovative Research on "Life Community" from the Perspective of Scientific Methodology. Studies in Dialectics of Nature, No. 11, 122.

Li, W. L. (2021). Reflections on the Marxist Theory of Western Ecology. Chinese Journal of Social Science, No. 5, 1.

Lin, J. R. (2018). Review of the Research on Ecological Marxism at Home over the Past 10 Years. Reform \& Openning, No. 19, 121.

Liu, R. Sh. (2006). An Overview of the Development of Ecological Marxism. Contemporary World and Socialism, No. 3, 62.

Liu, R. Sh. (2007). An Introduction to Ecological Marxism. Central Compilation \& Translation Press.

Meng, X. L. (2021). Critique on Capitalism from the Perspective of Ecological Marxism. Contemporary World, No. 9, 67.

Wang, Y. Ch. (2008). Theory of Ecological Civilization in Western Ecological Marxism: Three Dimensions and Significance. Journal of Huaihai Institute of Technology (Social Science Edition), No. 4, 2.

Wang, Y. Ch. (2019). On the Course and Implication of the Study of Ecological Marxism in China. Jianghan Tribune, No. 10, 55.

Wang, Y. Ch. (2021). The Problem Logic of Western Marxism and Its Contemporary Value. Marxism \& Reality, No. 4, 95.

Yu, G. Q. (2021). The Ecological Boundary of Modernity: The Modernity Criticism of Ecological Marxism and Its Limits. The Journal of Harbin Committee School of the CCP, No. 6, 43.

Yu, W. J., \& Chen, X. M. (2002). A New Edition of Foreign Schools of Marxist Philosophy (II). Fudan University Press.

Zhang, H. X., \& Jiang, N. (2020). Theoretical Analysis of Contemporary Western Ecological Marxism. Journal of Shengyang Jianzhu University (Social Science), No. 3, 278.

Zhong, S. M. (2016). Review of the Research on Ecological Marxism Both at Home and Abroad. Social Science Journal of University in Shanxi, No. 7, 4.

Zhu, H. J., \& Wu, Z. C. (2021). The Inheritance and Development of Marx's World History Theory by the Thought of Opening to the Outside World in the New Era. Journal of Shangqiu Normal University, No. 11, 41. 